\title{
A Comparative Study Regrinding the Buddhism in Burma
}

\author{
D.M.L. Harshika Bandara Dasanayaka \\ B.A. (Buddhist Coulter), Dip. in Counseling, (University of Ruhuna, Sri Lanka), M.A, (University of Buddhist \& Pali, Sri Lanka), M.phil, \\ (University of Kelaniya, Sri Lanka), Ph. D, Redding (University of Kelaniya, Sri Lanka) Dip. in HRM,
}

Assistant Lecture, Department of Pāli \& Buddhist Studies, University of Ruhuna

\begin{abstract}
There are various legends the pious Burmese cherish today on how Buddhism was first introduced to their country. They even claim that the Buddha was related to their early kings. The 'Glass Palace Chronicle' speaks about the first Sakyan kings of Burma and name Abhiraja, Dhajaraja and their dynasties. The 'New Pagan Chronicle' omits Abhiraja, but mentions Dhajaraja.
\end{abstract}

The popularly accepted tradition is that Buddhism came to Burma through two Talaing merchants, Taposa and Palika, (Tapassu andBhalluka in Pali) to whom the Buddha is believed to have given eight hairs of his head which he instructed them to deposit in the Theinguttara Hill beside the relics of the three Buddhas who preceded him. They returned to Burma and searched far and wide for Theinguttara Hill, which was finally pointed out to them by the aged Sule nat. Here they enshrined the hairs in a pagoda which came to be later known as the Shwe Dagon, one of the most sacred Buddhist shrines in the East. A pagoda was later built to commemorate the nat who had pointed out the sacred site; this is the present Sule Pagoda which stands in the centre of the city of Rangoon. The story of these two merchants is recorded in the Mahavagga, but there it is mentioned that they were from Ukkala (Utkala, Orissa in India). According to Burmese version, there was a dynasty and a geographical area called Ukkalapa there. The story recorded in Mahavagga, however, does not have any reference to a hair locks being given to them. Burmese maintain that when two local merchants started building a temple (Sandalwood Monastery) in the village called Lekaing, the Buddha came there to supervise the work personally. These legends only reflect the enthusiasm of the Burmese Buddhists to claim to be an early Buddhist country that received Buddhism before any other country outside India. As Sukumar Dutt puts it "We may put on one side these picturesque legends of the chronicles, obviously inventions of pious monks wishful to claim an impossibly high antiquity for Buddhism in their country." There are such stories told in Sri Lanka and Thailand also.A more probable tradition is that which states that Buddhism was brought to Burma by two monks, Sona and Uttara, who were sent out by the Third General Council, summoned under the patronage of the great Emperor Asoka, who flourished in India about 250 B.C.

The first people, according to the history and archaeology of Burma, who received Buddhism there were Pyu. It is from Chinese Tang Dynasty Annals (covering 609-918 AD) that we come to know about them. Pyus are described as Buddhists who had many monasteries in and around of their capitol Sri Ksetra (Tharekittara). Hsuan Tsang was told, when he was at Samatata in East Bengal in 640 AD, that there were Buddhist settlements at the other shore. And he was told of Sri Ksetra (in Chinese Shih-li-chata-lo). Nagarjunikonda inscription, as a matter of fact, refers to Buddhism in Burma as early as $3^{\text {rd }}$ century AD. Around 801 AD Pyus sent a group of musicians to entertain the Chinese Emperor. Until the invasion from Nanchao, which ruthlessly destroyed their capitol and taken many thousands of people captive, they seemed to have continued to have a rich culture.

The site of the Pyu Kingdom was around Hmawsa, old Prome in Central Burma. Archaeologists who explored it have found many Buddhist inscriptions and artefacts. Some gold plates containing Buddhist Pali passages were found in Maunggan village. Near Bawbawgyi Pagoda an inscription written in Andhra-Kannada script was found. In Kyawndawsa also a gold leaf was unearthed. And in the relic chamber of Khin Ba's mound they have found a gold leaf book which is written in South Indian Kadamba script belong to the fifth century. They have found many inscribed stone sculptures including the Nativity scene of the Buddha, Taming the elephant Nalagri, Dhammacakka sermon etc. Having carefully studied the findings, they have concluded that, the Pyus, although they were not ethnically related to India they had been highly influenced by Indian Culture. They wrote their language in South Indian script. They practised Theravada Buddhism and held Pali scripture in great reverence. There also was some who practised Hinduism.

Another group of people, who were also settled in Lower Burma, were Mons. They were a tribe widely distributed over southern Asia but they had their own cultural identity and a good deal of civilization that can be traced back to $5^{\text {th }}$ century. The Mons who settled down in Lower Burma and Siam called themselves Rmen. That was the word by which the Arab geographers coined the term Ramannadesa, the Country of the Mons, for Lower Burma and Siam.

From where the Mons obtained their Buddhism is not known. Dutt suggests that we should consider Indian settlements in Malayan peninsula, Ligor and other such areas. We may however not ignore the possibility of Sona and Uttara group of missionaries converting them to Buddhism. Mons had developed many legends, myths and literature passed from oral tradition and later crept into literature. Unlike Pyus, who are totally defused among other people, Mons kept their identity and culture relatively

\section{Volume 6 Issue 12, December 2017}




\section{International Journal of Science and Research (IJSR) \\ ISSN (Online): 2319-7064}

Index Copernicus Value (2016): 79.57 | Impact Factor (2015): 6.391

preserved. Early Mons had developed three kinds of legends Rajawan (legends of Ramanna kings and their legendary genealogies), Dhatuwan (legends of the great pagodas and their relics), and Pun (moral episodes from the lives of their kings).

While Mons, having settled in Lower Burma and Siam, were developing their own forms of culture, - especially under the influence of Buddhism,- their didactic literature, iconography, religious architecture and sculpture, a group of people called Thai, who migrated from Nanchao in China, were aggressively conquering shan states in upper Burma and also Siam. The group settled in Shan states were called by those in Siam as Thai Yai (Thai Elders). Then they started moving towards plains and their first foothold was Kyaukse. One charismatic leader who moved from the non Buddhist Shan states to the Kyaukse was Anauratha (Aniruddha, Anoratha or Anuruddha). It was there that the elder Thai got ethnically mixed with people there forming 'Mranma' (the term Burma is a derivative of this) and came face to face, for the first time, with Buddhism. Observes Dutt: "With their descent to the Kyaukse plains, started a process of assimilation, intermingling of blood and acculturation of the incoming 'elder Thai' marking the inception of the Burmese nationality."

Anauratha, from Kyaukse, proceeded to Pagan, which was an ancient capital town of Mons from seventh century. Even after the Nanchao invasion in 832 it regained its glory. According to the chronicles, the walls of Pagan were built in 849 and Mon kings were on the throne for about 160 years. There was a revival of Buddhism in Pagan under Caw Raham, the 'saint king', who built a sima as a mark of revival. In $1020 \mathrm{AD}$ Anauratha established his capital in Pagan. He is considered as the first 'Burmese' Buddhist king. He signed his name in Sanskrit as Aniruddha. Later he managed to expand his kingdom to south and rule entire Burma down to the sea.

How Anuruddha first came across Buddhism is not known. He was a worshipper of Naga and Nats and used Sanskrit as his religious language. Some terracotta figurines are found in ruins in Pagan and an inscription to the effect that they were handiwork of the king himself is also found. (Esah Lokanatha maharaja Sri Aniruddha deven krta vimuktyartham svahastenaiva $=$ This Lokanatha image is made by Maharaja Sri Aniruddha deva with his own hand for his salvation.)

The Bagan period, 1044-1287, was the golden age of both secular and religious history in Burma. Numerous pagodas were built which for architectural design and strength rivalled the Norman cathedrals which were being built at the same time in Europe, and in the opinion of some equalled them in beauty. Even today deserted though it is, Pagan with its sixteen square miles of pagodas and religious buildings is one of the wonders of the world.

Buddhism in Pagan at that time was contaminated with debased practices and many tantric cult rituals were adopted by so called 'Buddhist' priests. Those priests were called 'samana kuttakas' (eczemas on monkshood) in Sasanawamsa. Their cult was called 'Ari', which, according to the scholars, was a Tantric cult that had bred from a corruption of Mahayana Buddhism in Eastern India and was imported from there into Tibet where it was developed and dignified as a school of Buddhism. The Aris ministered a debased and nondescript cult compounded of magic, astrology, demonology, exorcism and the elements of Naga (serpents) and Nat (tutelary spirits) worship. They grew their hair and wore black robes. They enjoyed intoxicating drinks and sex. The belief in Kamma had no place in their teachings and sexual taboos were not recognised. The Glass Palace Chronicle mentions in particular the practice by the Ari priesthood of deflowering virgins on the night before marriage - the custom known in Anthropology as exercise of the 'right of the senior' (Le droit de signeur)

Anauratha had a feeling that that this could not have been proper Buddhism and was looking for someone who could enlighten him on the correct teachings of the Buddha. A huntsman, who knew the king's interest in saintly monks, one day, introduced an exemplary monk, whom he had met in the forest, to the King. The monk, Dhammadassi, who perhaps had a Thaton origin and later came to be known as Shin Arahant, explained to the king that the Sasana was threefold, (Pariyatti, Patipatti and Pativedha) and the first thing to be done, therefore, was to have the first - the scripture. By this time in the South, there was a Buddhist state ruled by a king called Manuha (Manohari) from Thaton. Although Thaton had pure Theravada Scripture in their possession they declined the request which prompted Anauratha to send an army, capture the king and the kingdom and to bring the scripture and some relics. Some monks and temple builders were also brought from south to establish Order of monks, built new stupas, shrines and monasteries in his land.

Anauratha managed to purge the Order by sending corrupt aris home and re-established the proper Sangha with the leadership of Dhammadassi. The first task at his hand was to translate the texts from Mon language Burmese. But after some time the Burmese started learning Pali which became Burma's classical language. By this time, in Sri Lanka, which had just emerged independent after a spell of foreign rule, there was a need for higher ordained monks to perform higher ordination there. Vijayabahu, the king of Sri Lanka send diplomats in 1071 to Anauratha asking for assistance which was duly extended. There was request from the Burmese king for tooth relic and a set of Pali scripture. Sri Lankans manage to donate a replica (claimed to have been a miraculously generated by requesting the holy object to double) of the tooth relic. Its arrival at Pagan was the occasion of another triumphant procession: the king himself waded out into the river and bore the sacred relic on his head to be enshrined in the Shwezigon pagoda with other Buddha relics. Anawratha's action in sending monks to Ceylon was repaid more than once in, the history of Burmese Buddhism, for when the number of genuinely ordained monks became so low as to threaten the true succession, missions were sent from Ceylon to ensure its unbroken continuance. The scripture brought from Sri Lanka was accepted with reverence copied and studied comparing with Thaton version. It is believed that Thaton scripture also was brought there some centuries before Anauratha got it from there by a monk called Buddhaghosa. (A life story compiled later 


\section{International Journal of Science and Research (IJSR) ISSN (Online): 2319-7064}

Index Copernicus Value (2016): 79.57 | Impact Factor (2015): 6.391

confusingly identifies this monk with the commentator Buddhaghosa).

Anauratha died after 33 years of reign, but Shin Arahan survived to continue all good religious work the king initiated. His successors continued his policy of religious patronage and temple-building. His son Kyansittha, 10841112, was as fortunate as his father in having for the whole of his reign Shin Arahan as Primate and adviser. A mission was sent to India to restore the shrine at Buddhagaya, where was the sacred Bo tree under which the Buddha had become enlightened. Kyan-sittha also built the lovely Ananda pagoda, in the Western aisle of which can still be seen two life-size figures of himself and Shin Arahan kneeling at the feet of a gigantic image of the Buddha. Pali studies kept growing and Buddhism flourished all over the land. Intercourse with Sri Lanka was sustained and as a result, in 1190, a vigorous monk organisation called Sihala Sangha also came forth. This, of course was result of the continuing enthusiasm on purity of higher ordination and Buddhist learning and the dependence for this on Sri Lanka by the Burmese monks. Shin Arahan died in 1115 at the age of 71; it is to him more than to any other person that we owe the establishment of the pure form of Hinayana Buddhism in Burma, and the era of pagoda-building and inscriptions which he inaugurated was the most creative age in Burma's history.

Shin Arahan's successor in primacy, Panthagu, retired to Sri Lanka in his old age. And Panthagu's successor Uttarajiva visited Sri Lanka in 1170 (1170 according to Kalyani inscription. Yet he is reported to have visited during king Narapatisithu's time, who ascended to throne only in 1173) and was conferred the honorific title 'the first pilgrim to Sri Lanka'. He brought a samanera called Chapata to Sri Lanka, who studied there for ten years and obtained higher ordination. According to Kalyani inscription he returned to Burma in 1081 with four more mahatheras (Sivali, a native of Tamalitthi; Tamalinda, a son of the king of Cambodia; Ananda of Kancipura; Rahula of Sri Lanka) who had Mahavihara higher ordination. He, with support of the king Narapathisithu, established a sima in the Irravadi river and higher ordained many Burmese monks in the Sri Lanka way and established Sinhala Sangha.

Pagan continued as a politically powerful and religiously active centre until Timur destroyed the city and droved away the population further south. Harvey in his History of Burma pays the following inspired tribute to this dynasty of templebuilders: 'The legacy of their fleeting sway enriched posterity for ever. It was they who made the sun-scorched wilderness, the solitary plain of Myingyan, to blossom forth into the architectural magnificence of Pagan. . . . To them the world owes in great measure the preservation of Theravada Buddhism, one of the purest faiths mankind has ever known. Brahmanism had strangled it in the land of its birth. In Ceylon its existence was threatened again and again. East of Burma it was not yet free from priestly corruptions. But the Kings of Burma never wavered, and at Pagan the stricken faith found a city of refuge. Vainglorious tyrants build themselves sepulchres, but none of these men has a tomb. . . . These men's magnificence went to glorify their religion, not to deck the tent wherein they camped during this transitory life.'

Pagan kingdom broke up in 1287; for years it had been weakening and none of its later kings had been men of any great note, but the immediate cause was the invasion of the Chinese to whom Pagan had been nominally tributary for some time. The break-up of the Bagan kingdom was followed by a period of Shan invasion. These were naturally years of confusion, and Buddhism shared in the general decline. Religion languished, the clergy split up into sects, though pagodas were built none of them could rival even the lesser temples of Pagan.

After two troublesome centuries, a fresh cultural centre emerged in Pegu and remained the capital till 1539. King Dhammaceti (1472-1492) was one of the most devoted and active Buddhist kings who ruled from Pegu.

He built some beautiful pagodas at Pegu, modelled on the temple at Buddhagaya to which he sent a mission.

He used to be Buddhist monk but on the invitation of Queen Shinsawbu (1453-1472) agreed to succeed to throne. He proved to be a very intelligent, wise and beneficent king. His reign marked a new revival of Buddhism in Burma. Owing to troubles that the country had to undergo, the Buddhist practices were neglected and the Sangha split into several sects. The king wanted to reform the Sangha and unify the sects. There were controversies on the propriety of Sima and the correct procedure of higher ordination. As the king did not believe the procedure adopted in Burma that time, he wanted to reintroduce higher ordination from Sri Lanka. He sent a religious mission comprised of 22 monks and 22 others (novices and pupils) who arrived in Sri Lanka in 1476. King Buvanekabahu VI of Sri Lanka assisted them to obtain higher ordination at a sima in Kelaniya. Those monks, on their return, established a fresh sima and named it Kalyani and started offering higher ordination to Burmese monks. During the period of 1476-1479, 15666 monks obtained higher ordination. Among them 800 were leading monks. The king brought the Sangha under on ecclesiastical authority and made a great contribution to bring back the lost glory to Buddhism. Among the monks who went on this mission was Buddhaghosa, who translated the earliest Burmese law-book the Wareru Dhamma-that, based on the laws of Mann brought by Hindu colonists to Burma centuries before. He also wrote various commentaries. Burmese historians have identified him with the famous Buddhaghosa who was born in India and translated many of the Scriptures and commentaries from Singhala into Pali.. But Burmese historians have a naive way of identifying places and personalities mentioned in the Scriptures and commentaries with places and personalities in Burma, without real foundation. The truth is that the early history of Buddhism in Burma has been lost, and writers convinced of its long standing in the country have sought to make good the lack.

While Burma had to face many internal wars and invasions from Siam and Arakan, Buddhism retained its influence on the Burmese culture. Kings build pagodas, dedicate slaves, and endow monasteries with paddy land. King Bayin Naung 


\section{International Journal of Science and Research (IJSR) \\ ISSN (Online): 2319-7064}

Index Copernicus Value (2016): 79.57 | Impact Factor (2015): 6.391

(1551-1581) who unified Burma after conquering the Shan States was a warrior king but displayed fervent faith Buddhism. He banned animal sacrifice and burying people alive; suppressed the custom of slaughtering too each of men and women, too horses and to elephants to be the retinue on his last journey of any sawbwa who died. He carried out a reformation of Sangha and organised dhamma discussions and distribution of scripture among the temples. He came to know that in Sri Lanka Portuguese had consecrated a puppet Christian king asked him to send the tooth relic to him. This time also Burma got only a duplicate. He is reported have made a pilgrimage to important Buddhist places like Shwedagon (Yangon), Shwezigon (Pagan), Shwesando (Prome).

With the 16th century came adventurers and traders from the West, first the Portuguese, then the Dutch, French and English. Captain Alex Hamilton, who visited Syriam in 1709 , pays a striking tribute to the humanity and hospitality of the old-time priesthood of Burma : 'When shipwrecked mariners come to their Bass, they find a great deal of hospitality, both in food and raiment, and have letters of recommendation from the Priests of one Convent to those of another on the road they design to travel, where they may expect vessels to transport them to Syriam ; and if any be sick or maimed, the Priests, who are the chief Physicians, keep them in their Convent, till they are cured, and then furnish them with letters, as is above observed, for they never enquire which way a stranger worships God, but if he is human; he is the object of their charity.

In 1784-5 King Bodawpaya invaded Arakan and brought away the great Maha-muni image of the Buddha. It was taken on rafts to Sandoway and thence over the Taungup pass to Padaung below Prome, and thence up the Irrawaddy to be enshrined in the Arakan pagoda at Mandalay, a tremendous triumph of transport. He attempted to reform the monks. His religious and secular triumphs evidently turned his brain, for he thought himself destined to be a world conqueror, and not content with this claimed to be the final Buddha. This latter claim however was firmly rejected by the monks.

In 1871 King Mindon summoned 2,400 clergy to Mandalay to attend the Fifth Buddhist Council. The assembled monks following the custom of the earlier councils, recited the Buddhist Scriptures, and the accepted text was engraved on 729 marble slabs erected in the Kutho-daw pagoda. Although only Burmese clergy had been invited Mindon received the proud title of Convener of the Fifth Great Synod'. As a memorial of this council King Mindon presented a new spire to the Shwe Dagon pagoda, coated with gold and studded with jewels, costing $£ 62,000$.

With the annexation of Upper Burma in 1885 by British Buddhism ceased to be the state religion of any part of Burma. Harvey in the Cambridge History of India has the following interesting and pungent paragraph: `The King was head of the Buddhist Church. His chaplain was a primate who prevented schism, managed church lands, and administered clerical discipline, through an ecclesiastical commission appointed and paid by the King. The primate prepared the annual clergy list, giving particulars of age and ordination, district by district, and any person who claimed to be a cleric and was not in the list was punished. A district governor was precluded by benefit of the clergy from passing judgment on a criminous cleric, but he framed the trial record and submitted it to the palace; the primate passed orders, unfrocking the cleric and handing him over to secular justice. In 1887, the primate and thirteen bishops met the commander-in chief, Sir Frederick Roberts, offering to preach submission to the English in every village throughout the land, if their jurisdiction was confirmed. The staff trained by the English in Lower Burma for two generations included Burmese Buddhist extra commissioners who could have represented the chief commissioner on the primate's board. But English administrators, being citizens of the modern secularist state, did not even consider the primate's proposal; they merely expressed polite benevolence, and the ecclesiastical commission lapsed. Today schism is rife, any charlatan can dress as a cleric and swindle the faithful, and criminals often wear the robe and live in a monastery to elude the police. As Sir Edward Sladen, one of the few Englishmen who had seen native institutions as they really were, said, the English non-possums were not neutrality but interference in religion.'

\section{Special characteristics of Burmese Buddhism}

Burmese Buddhism has been from the time of Anauratha, mainly Theravada in nature. Abhidhamma is given a very important place in Buddhist learning and any one who has not studies Abhidhamma is not accepted as a learned Buddhist scholar. The Theravada commentaries compiled by Buddhaghosa are always considered as authoritative. How much they respect and identify themselves with the commentaries can be seen in their claim of Buddhaghosa being a Burmese. However, they have special respect to meditating monks and when those monks offer variant interpretations they tend to respect those also. They held a Buddhist Council in the middle of the $20^{\text {th }}$ century to commemorate the 2500 Buddha Jayanti and rehearsed and edited the Tipitaka.

Monkhood is considered as a very important institution and every male is expected to enter it for sometime. No one can enter into married life if he had not spend sometime in a monastery as a monk.

They are, according to some writers, more expressive in their religious monuments rather than in literature. There are many thousands of Pagodas all over the land enshrining various relics. As all villages and towns are full of pagodas it is sometimes described as 'Pagoda land'. Shwedagon is the most respected pagoda (302 feet high) which claims a legendary history to have relics of the four Buddhas in this aeon. The first historical pagoda is Shwezigon, started by Anauratha in in 1054 and completed by Kyanzittha. The most recent large stupa is Mahavijaya, built to celebrate the unification of Sangha.

It was a tradition among the Buddhist kings of Burma to dedicate a stupa by himself to symbolize his adherence to Buddhism. When a pagoda became famous, it was usual to celebrate its history, legendary or authentic, in a thamaing (historical narrative). Burmese pagoda is different from

\section{Volume 6 Issue 12, December 2017}




\section{International Journal of Science and Research (IJSR) \\ ISSN (Online): 2319-7064}

Index Copernicus Value (2016): 79.57 | Impact Factor (2015): 6.391

usual Indian stupa as it has replaced the usual dome and overtopping harmika by astaight spire soaring flame like towards sky. People keep on affixing gold leaves to the pagodas as a deed of merit. Shwedagon is believed to have seven tons of gold leaves affixed to it.

A class of labourers called 'Purha Kywan'" (Pagoda slaves) grew up in Burma who dedicated to the service of pagodas. Not only layman, even monks beacame purha kywans. They were workmen as well as caretakers and enjoyed special status. They were forbidden to do any work in the villages.

Nat worship which is a pre-Buddhistic practice has not gone out of practice even though Buddhism has deeply rooted among the Burmese. They are incorporated to the Buddhist pantheon as protective deities. This assimilation process was actually commenced by Anauratha by placing all 37 nat statues around the Shwedagon pagoda. In the pre Buddhist times the number of Nats were only 36. But the Buddhists added god Sakka as their leader making the number increase to 37. Thereafter the number remained unchanged but, time to time the list got revised. The presently valid list was made official by King Bodawpaya in 1885.

Sir R.C.Temple wrote: "In order to understand the daily life and aspirations of the ordinary Burman, it is not sufficient that he is by professed religion a Buddhist and to understand what his Buddhism teaches. It is necessary to know also that he is a firm believer in Nats or spirits and to grasp how the superstitions connected with this faith affect him in his daily life and notions."

\section{References}

[1] Pranke, Patrick, 2013, Myanmar, Encyclopaedia of Buddhism, Macmillan, USA.

[2] Ferguson, John P. E. and Michael Mendelson, 1981, Masters of the Buddhist Occult: The Burmese Weikzas. Essays on Burma.

[3] Aung, Thwin, Michael, 1985, The Origins of Modern Burma, University of Hawaii Press, Honolulu,

[4] Charney, Michael W. 2006, Powerful Learning Buddhist Literati and the Throne in Burma's Last Dynasty, The University of Michigan.

[5] Matthews, Bruce, 1999,"The Legacy of Tradition and Authority: Buddhism and the Nation in Myanmar", in: Ian Harris (ed.), Buddhism and Politics in TwentiethCentury Asia. Continuum, London, New York

Volume 6 Issue 12, December 2017 www.ijsr.net 